\title{
As línguas Tupí faladas dentro e fora da Amazônia. Martins, Marci Fileti (Org.). Rio de Janeiro: Museu Nacional, 2017. http://www.museunacional.ufrj.br/ publicacoes/wp-content/arquivos/LivDigital12.pdf
}

\author{
Recenseado por Maxwell Gomes Miranda, Universidade Federal do Mato
}

Grosso

A diversidade de línguas e culturas indígenas existente no Brasil tem sido cada vez mais destacada, nos últimos anos, em eventos e publicações científicas específicas da área. As pesquisas linguísticas sobre essa diversidade são relevantes não só para a compreensão da linguagem humana, sob distintos enfoques teóricos, mas também para que o conhecimento produzido sobre elas retorne em forma de subsídios para o desenvolvimento tanto de metodologias adequadas para sua documentação, quanto de políticas linguísticas para a sua valorização, manutenção e fortalecimento.

Dentro desse cenário promissor, o livro, As línguas Tupí faladas dentro e fora da Amazônia, organizado pela Dr. ${ }^{a}$ Marci Fileti Martins, é uma importante contribuição visto que os temas abordados pelos artigos contribuem para ampliar e aprofundar a compreensão sobre os mecanismos formais e funcionais que caracterizam a organização gramatical das línguas Tupí, assim como traz elementos para se refletir sobre a educação escolar e as políticas linguísticas para os povos indígenas.

O livro, que é composto de 8 artigos produzidos por especialistas em línguas do tronco Tupí, sendo um deles em coautoria com pesquisadores indígenas Tuparí, examina nove línguas: Tuparí, Makuráp e Akuntsú (família Tuparí), Tenetehára, Uru Eu Wau Wau, Guaraní (Mbya, Guaraní (Boliviano), Guaraní Paraguaio), Asuriní do Trocará (família Tupí-Guaraní) e o Português Mbya Guarani, que é uma variedade do português falada pelos Guarani Mbya do estado do Rio de Janeiro.

Divide-se em dois conjuntos complementares. O primeiro conjunto é dedicado à análise e descrição linguísticas, e ainda que sob diferentes quadros teóricos, tanto na perspectiva descritiva quanto gerativista, os resultados destacam propriedades gramaticais recorrentes nas famílias do tronco Tupí relacionadas a morfologia de caso (família Tupari), sistemas de alinhamento morfossintático e a marcação pessoa e caso, processos de formação de palavras, complexos verbais e ordem de constituintes (família Tupí-Guaraní). Na segunda parte, os artigos discutem questões voltadas para a Educação Escolar 
Indígena relativas à formação de professores indígenas no estado de Rondônia e à institucionalização de políticas linguísticas por diversas agências, objetivando a promoção e a valorização da língua Guaraní no Paraguai, Bolívia e Brasil.

O Livro As línguas Tupí faladas dentro e fora da Amazônia chega em momento oportuno ao público acadêmico, e não atende somente estudantes e pesquisadores da área de Letras e Linguística, mas também profissionais da Educação que estão direta ou indiretamente envolvidos com as respectivas comunidades indígenas para fins de assessoria pedagógica. E ainda que alguns artigos exijam do leitor domínio da terminologia sobre o quadro teórico a partir do qual foram fundamentados, como é o caso do modelo gerativo, a linguagem adotada é clara e objetiva, de acordo com os propósitos de cada texto.

Apesar de haver uma considerável bibliografia sobre estudos linguísticos voltados para as línguas Tupí, é com entusiasmo que o público acadêmico recebe mais essa obra, que aprofunda análises acerca da gramática das línguas do agrupamento genético em destaque, e na mesma medida mostra experiências de como o conhecimento científico produzido a partir delas, pode ser revertido em ações de formação docente e políticas linguísticas que buscam dar visibilidade à rica e complexa diversidade de línguas e culturas indígenas do Brasil e de outros países adjacentes. Assim, a publicação As línguas Tupi faladas dentro e fora da Amazônia cumpre fielmente seu objetivo que é contribuir para o conhecimento sobre as línguas do tronco Tupí. 